\title{
Determination and Quantification of Trace Elements, by ICP_MS, in the River Water of Sarzhal and Akzhar Villages
}

\author{
Zhanibek Yessimbekov $^{1 *}$, Duyssembaev Sergazy ${ }^{1}$, Dilraba Iminova ${ }^{1}$, Eleonora Okushanova ${ }^{1}$, \\ Marilyne Stuart ${ }^{2}$ \\ ${ }^{1}$ Shakarim Semey State University, Semey, Republic of Kazakhstan; ${ }^{2}$ Atomic Energy of Canada Limited (AECL), Mississauga, Canada. \\ Email:"ezhanibek@mail.ru
}

Received July 24 $4^{\text {th }}, 2013$; revised August 27 $7^{\text {th }}, 2013$; accepted September $23^{\text {rd }}, 2013$

Copyright (C) 2013 Zhanibek Yessimbekov et al. This is an open access article distributed under the Creative Commons Attribution License, which permits unrestricted use, distribution, and reproduction in any medium, provided the original work is properly cited.

\begin{abstract}
In the present study, trace elements present in the river waters of Sarzhal and Akzhar region were measured using inductively coupled plasma mass spectrometry (ICP-MS). The reason for monitoring trace elements at those two locations is to verify water quality. The village of Sarzhal is situated in an area that has been affected by weapon testing and continues to receive inputs of contaminants (including radionuclides). The concentrations of trace elements in the river water of Sarzhal and Akzhar villages were generally found to be within allowable levels. However, the concentrations of $\mathrm{Na} 251.56 \mathrm{mg} / \mathrm{l}, \mathrm{Cr} 3.26 \mu \mathrm{g} / \mathrm{l}, \mathrm{P} 64.56 \mu \mathrm{g} / \mathrm{l}$ and Se $18.162 \mu \mathrm{g} / \mathrm{l}$ in the river of Akzhar were found to be higher than the maximum allowable concentrations (MAC). In Sarzhal, the level of Al $6.66 \mathrm{mg} / \mathrm{l}, \mathrm{Cr} 5.04 \mu \mathrm{g} / \mathrm{l}$ and P $13.44 \mu \mathrm{g} / \mathrm{l} \mathrm{ex}-$ ceeded the MAC values.
\end{abstract}

Keywords: River Water; Trace Element; Mass-Spectrometry; Sarzhal; Akzhar

\section{Introduction}

Water is essential for life and its quality is important for public health and safety [1]. Water is also an important source of trace elements that are required for life as some trace elements play important biochemical roles [2]. However, excess of essential trace metals (like Fe, Mn, $\mathrm{Cu}, \mathrm{Zn}, \mathrm{Co}, \mathrm{Ni}$, etc) can be toxic. Deficiency or excess in the human system can lead to a number of disorders. Other trace metals (like $\mathrm{Pb}, \mathrm{As}, \mathrm{Hg}$, etc) are not essential and can definitely be toxic above certain levels [3]. Trace metals can be considered toxicants that are widely distributed in the environment, with sources mainly from the weathering of minerals and soils $[4,5]$.

On the other hand, monitoring water quality is especially important in East Kazakhstan, because of the introduction of contaminants by nuclear tests that were carried out at the Semipalatinsk Nuclear Test Site (SNTS). SNTS covers a portion of the northwestern part of the East Kazakhstan oblast (formerly known as the Semipalatinsk oblast), as well as parts of the Pavlodar and Karaghandy oblasts (oblasts are administrative units, similar to states in the U.S.) [6].

"Corresponding author.
Information on the distribution of trace elements in the river water of Sarzhal and Akzhar villages are very limited and water from these rivers is mainly used for agriculture and animal husbandry purposes. The Chagan river is recharged within the limits of the SNTS and flows along the village of Sarzhal, on the east side of SNTS. At the end of its path, the Chagan river meets the Irtysh River that passes through the city of Semey. The length of the Chagan river is $275 \mathrm{~km}$, including $50 \mathrm{~km}$ along the "Balapan Site", flowing to Atomic Lake (the water-collecting area near the test tunnels is around $900 \mathrm{~km}^{2}$ ).

The purposes of this study were to quantify trace elements in the river waters sampled from the settlements adjoining to the SNTS, to compare the measured concentrations with the Republic of Kazakhstan maximum allowable concentration (MAC) values and to report the findings such that appropriate actions are taken to protect the local populations.

\section{Materials and Methods}

\section{Study Area}

All together 467 nuclear tests were conducted within the 
SNTS polygon (which covers an area of $18,500 \mathrm{~km}^{2}$ ). It appears that the Opytnoe Pole (located in the North-West) was used for all air and surface testing while the other regions were used for underground testing [6]. Opytnoe Pole was reported to be the site of 86 nuclear tests in the air and 30 on the ground. It was also reported to have been used for battle tests using nuclear materials (no bombs). The Balapan region, to the East of the SNTS where Atomic Lake is located, covers an area of about $780 \mathrm{~km}^{2}$. According to the reports, it was the site of 105 underground nuclear tests [7]. The Degelen region, middle-South of the SNTS, covers an area of about $300 \mathrm{~km}^{2}$. It was reported to be the site of 209 underground nuclear tests [8]. Another testing area was Sary-Ozen, located in the South-West of the SNTS, where 24 underground nuclear tests have been reported [9].

The village of Sarzhal is situated on the South-East border of the SNTS. The village was contaminated by radionuclides and metals due to the nuclear tests. For this area, the most important contamination event was reported to be the testing of the first thermonuclear explosion that took place on the Opytnoe Pole 23 August, 1953 [10]. Other potential sources of contamination, for the population of this village, include the sites of explosions of Tel'kem 1 and Tel'kem-2, which are situated within the Balapan region but several dozen of kilometers from Sarzhal (The 2 craters are currently filled with groundwater and animals have been seen drinking from these craters.) and the Degelen mountains [10]. For this area, most of the contamination originates from underground testing.

The village of Akzhar is situated on the North border of the SNTS. The main potential source of contamination was the nuclear tests which were carried out on "The Experimental field" site also known as the Opytnoe Pole. Test site area and adjacent territories were exposed repeated to radioactive and metal contamination. In this region, the main sources of contamination were from atmospheric explosions.

All of these settlements are shown in Figure 1.

Water samples were collected from the rivers of Akzhar and Sarzhal villages during the summer of 2012.

15 samples were collected along the river from 5 sampling locations ( 3 samples were collected at each location). The samples were obtained from Akzhar to about 1 $\mathrm{km}$ downstream of the village. Similarly, 15 samples were obtained starting from the Sarzhal village to about 1 $\mathrm{km}$ upstream of the village. The sample volumes taken were between 1.5 and 2.0. The ambient temperature was $25^{\circ} \mathrm{C}$ and the water temperature was $18^{\circ} \mathrm{C}$ at the time of sampling for the river of the Sarzhal village. The ambient temperature was $23^{\circ} \mathrm{C}$ and the water temperature was $17^{\circ} \mathrm{C}$ at the time of sampling for the river of the Akzhar village. The samples were collected by pouring

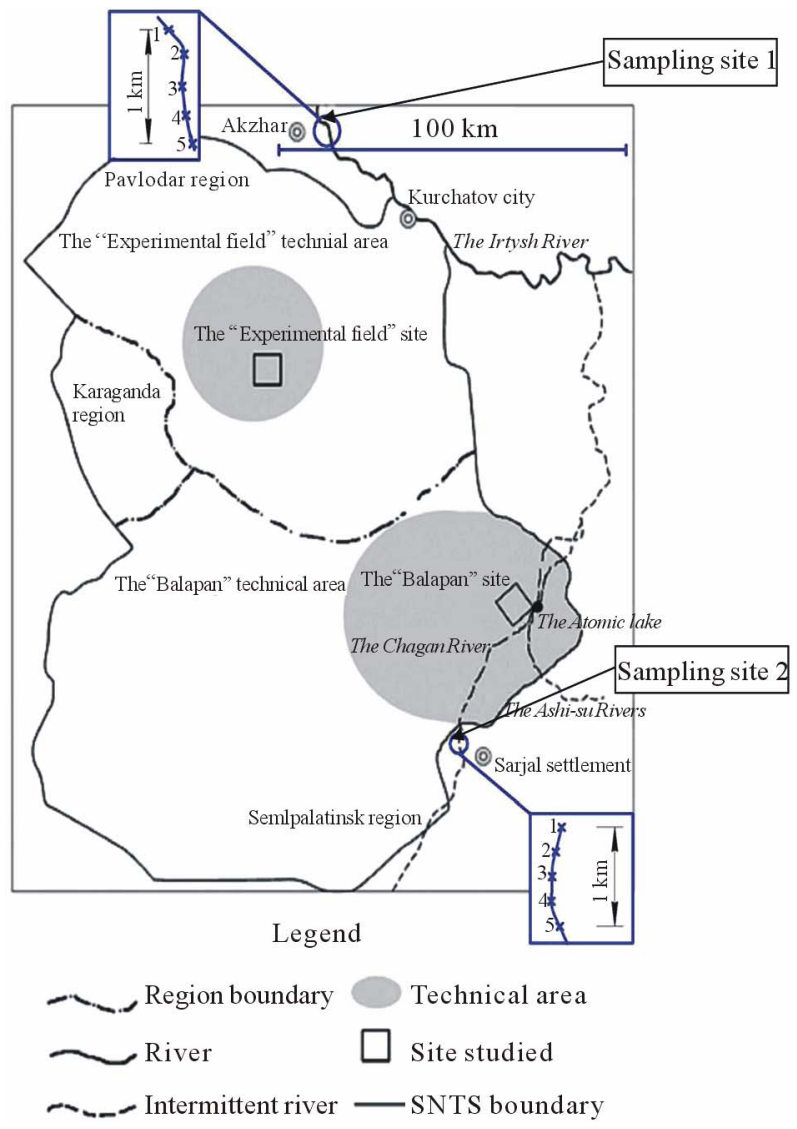

Figure 1. Simplified map of SNTS depicting the sampling locations.

water into plastic polyethylene bottles. The bottles were then labeled and transported to the laboratory. The samples were kept at ambient temperature during the transport and storage. The samples were transferred to the laboratory and acidified with $1-2 \mathrm{ml}$ of concentrated nitric acid $(\mathrm{pH}<2)$.

At the sampling locations, the dose rates were measured, using a radiometer "RKS-01-SOLO" ("Solo" Company, Kazakhstan), dosimeter-radiometer "MKS-AT6130" (“Atomtech" Company, Belarus).

Trace elements were identified and quantified using inductively coupled plasma mass spectrometry (ICP-MS) Varian-820 MS (Varian Company, Australia). Calibration standards Var-TS-MS, IV-ICPMS-71A (Inorganic Ventures Company, USA) were used for calibrating the mass-spectrometer: sensitivity of the mass-spectrometer was tuned up using a diluted calibration solution Var-TSMS with concentration of $\mathrm{Ba}, \mathrm{Be}, \mathrm{Ce}, \mathrm{Co}, \mathrm{B}, \mathrm{Pb}, \mathrm{Mg}, \mathrm{Tl}$, Th of $10 \mu \mathrm{g} / \mathrm{l}$. Three calibration solutions were used for the detector calibration. They were IV-ICPMS-71A of $\mathrm{Ag}, \mathrm{Al}, \mathrm{As}, \mathrm{B}, \mathrm{Ba}, \mathrm{Be}, \mathrm{Ca}, \mathrm{Cd}, \mathrm{Ce}, \mathrm{Co}, \mathrm{Cr} 3, \mathrm{Cs}, \mathrm{Cu}, \mathrm{Dy}$, Er, Eu, Fe, Ga, Gd, Ho, K, La, Lu, Mg, Mn, Na, Nd, Ni, $\mathrm{P}, \mathrm{Pb}, \mathrm{Pr}, \mathrm{Rb}, \mathrm{S}, \mathrm{Se}, \mathrm{Sm}, \mathrm{Sr}, \mathrm{Th}, \mathrm{Tl}, \mathrm{Tm}, \mathrm{U}, \mathrm{V}, \mathrm{Yb}, \mathrm{Zn}$ elements diluted to 10,50 and $100 \mu \mathrm{g} / 1$. 


\section{Results}

The levels of background radiation at the sampling sites were: $0.11-0.13 \mu \mathrm{Sv} / \mathrm{h}$ at the Sarzhal river and $0.10-$ $0.12 \mu \mathrm{Sv} / \mathrm{h}$ at the Akzhar river. Tables 1 and 2 present the concentration of trace elements in Akzhar and Sarzhal river waters, respectively.

Some trace element concentrations were found to be variable. For example, in the river of Akzhar the values obtained ranged between 44.8 and $325 \mathrm{mg} / \mathrm{l}$ of $\mathrm{Na}, 16.7$ to $83.9 \mathrm{mg} / \mathrm{l}$ of $\mathrm{Ca}, 27.8$ to $75.9 \mathrm{mg} / \mathrm{l}$ of $\mathrm{Mg}, 0.02$ to 2.10 $\mathrm{mg} / \mathrm{l}$ of $\mathrm{Zn}, 0.05$ to $1.51 \mathrm{mg} / \mathrm{l}$ of $\mathrm{Cu} ; 0.07$ to $5.0 \mu \mathrm{g} / \mathrm{l}$ of $\mathrm{V}$,
0.07 to $2.04 \mu \mathrm{g} / \mathrm{l}$ of $\mathrm{Pb}, 0.95$ to $82.0 \mu \mathrm{g} / \mathrm{l}$ of Se and 18.98 to $109.0 \mu \mathrm{g} / \mathrm{l}$ of P. In water samples of Akzhar the concentrations of $\mathrm{Na}, \mathrm{Cr}, \mathrm{P}$ and $\mathrm{Se}$ were found to exceed the MACs (Figure 2).

Trace element concentrations also showed some variability in the river of Sarzhal. For example the ranges were 58.2 to $278.0 \mathrm{mg} / \mathrm{l}$ for $\mathrm{Ca}, 1.25$ to $6.92 \mathrm{mg} / \mathrm{l}$ for $\mathrm{K}$, 0.002 to $10.8 \mathrm{mg} / 1$ for $\mathrm{Al} ; 0.08$ to $4.50 \mu \mathrm{g} / \mathrm{l}$ for $\mathrm{V}, 1.35$ to $6.82 \mu \mathrm{g} / \mathrm{l}$ for Ni, 3.38 to $42.0 \mu \mathrm{g} / \mathrm{l}$ for $\mathrm{Ba}, 0.95$ to $4.00 \mu \mathrm{g} / \mathrm{l}$ for As, 0.1 to $2.15 \mu \mathrm{g} / 1$ for $\mathrm{Pb}, 2.36$ to $21.9 \mu \mathrm{g} / 1$ for $\mathrm{P}$. The levels of $\mathrm{Al}, \mathrm{Cr}$ and $\mathrm{P}$ exceeded the MACs (Figure 2).

Table 1. Concentrations of trace elements in Akzhar river water at the 5 sampling locations.

\begin{tabular}{|c|c|c|c|c|c|c|c|}
\hline Trace element & 1 & 2 & 3 & 4 & 5 & Median & MAC \\
\hline \multicolumn{8}{|c|}{$\mathrm{mg} / \mathrm{l}$} \\
\hline $\mathrm{Na}$ & $44.8 \pm 2.3$ & $325 \pm 11$ & $296 \pm 12.4$ & $303 \pm 9.1$ & $289 \pm 11$ & $252 \pm 9.2$ & 200 \\
\hline $\mathrm{Ca}$ & $83.9 \pm 3.0$ & $16.7 \pm 0.6$ & $71.7 \pm 2.1$ & $49.9 \pm 1.5$ & $51.8 \pm 1.5$ & $54.8 \pm 1.7$ & 140 \\
\hline $\mathrm{Mg}$ & $75.9 \pm 2.3$ & $52.3 \pm 1.6$ & $33.4 \pm 0.8$ & $32.3 \pm 0.8$ & $27.8 \pm 0.8$ & $44.3 \pm 1.3$ & 85 \\
\hline $\mathrm{K}$ & $3.76 \pm 0.08$ & $4.78 \pm 0.15$ & $8.72 \pm 0.26$ & $7.17 \pm 0.22$ & $2.95 \pm 0.08$ & $5.48 \pm 0.15$ & 12 \\
\hline $\mathrm{Sr}$ & $0.23 \pm 0.011$ & $0.93 \pm 0.011$ & $0.74 \pm 0.018$ & $0.70 \pm 0.018$ & $0.63 \pm 0.018$ & $0.65 \pm 0.015$ & 7 \\
\hline $\mathrm{Zn}$ & $0.70 \pm 0.04$ & $0.83 \pm 0.04$ & $1.13 \pm 0.03$ & $2.10 \pm 0.06$ & $<0.02$ & $0.96 \pm 0.03$ & 5 \\
\hline $\mathrm{Cu}$ & $0.59 \pm 0.017$ & $0.57 \pm 0.017$ & $1.51 \pm 0.046$ & $<0.13$ & $<0.05$ & $0.57 \pm 0.03$ & 1 \\
\hline $\mathrm{Al}$ & $<0.04$ & $<0.18$ & $<0.07$ & $<0.07$ & $<0.01$ & $<0.07$ & 0.5 \\
\hline $\mathrm{Fe}$ & $<0.03$ & $<0.07$ & $<0.04$ & $<0.07$ & $0.15 \pm 0.010$ & $<0.07$ & 0.3 \\
\hline \multicolumn{8}{|c|}{$\mu g / l$} \\
\hline $\mathrm{Cr}$ & $2.2 \pm 0.06$ & $2.7 \pm 0.06$ & $2.10 \pm 0.06$ & $3.30 \pm 0.11$ & $6.00 \pm 0.22$ & $3.30 \pm 0.10$ & 0.5 \\
\hline V & $<0.07$ & $<0.02$ & $<0.06$ & $<0.16$ & $5.0 \pm 0.15$ & $1.06 \pm 0.15$ & 100 \\
\hline $\mathrm{Mn}$ & $1.11 \pm 0.04$ & $1.73 \pm 0.06$ & $1.59 \pm 0.05$ & $1.94 \pm 0.06$ & $1.20 \pm 0.04$ & $1.51 \pm 0.05$ & 100 \\
\hline Co & $<0.03$ & $<0.04$ & $<0.05$ & $<0.06$ & $0.170 \pm 0.013$ & $0.070 \pm 0.013$ & 100 \\
\hline $\mathrm{Ni}$ & $1.07 \pm 0.03$ & $1.04 \pm 0.03$ & $1.22 \pm 0.04$ & $1.56 \pm 0.05$ & $0.95 \pm 0.03$ & $1.17 \pm 0.04$ & 100 \\
\hline As & $<0.05$ & $<0.05$ & $0.39 \pm 0.012$ & $0.60 \pm 0.02$ & $6.70 \pm 0.20$ & $1.56 \pm 0.08$ & 50 \\
\hline $\mathrm{Ag}$ & $<0.02$ & $<0.01$ & $<0.16$ & $<0.06$ & $<0.03$ & $<0.05$ & 50 \\
\hline $\mathrm{Pb}$ & $0.65 \pm 0.02$ & $0.76 \pm 0.03$ & $2.04 \pm 0.06$ & $1.04 \pm 0.03$ & $<0.07$ & $0.91 \pm 0.04$ & 30 \\
\hline $\mathrm{Se}$ & $1.55 \pm 0.06$ & $1.81 \pm 0.06$ & $0.95 \pm 0.03$ & $4.50 \pm 0.14$ & $82.0 \pm 2.5$ & $18.16 \pm 0.56$ & 10 \\
\hline $\mathrm{Cd}$ & $<0.066$ & $<0.082$ & $<0.203$ & $<0.126$ & $<0.006$ & $<0.096$ & 1 \\
\hline $\mathrm{P}$ & $48.50 \pm 1.70$ & $91.32 \pm 3.10$ & $55.0 \pm 1.7$ & $18.98 \pm 0.62$ & $109.0 \pm 3.3$ & $64.56 \pm 2.08$ & 0.1 \\
\hline
\end{tabular}

Table 2. Concentrations of trace elements in Sarzhal river water at the 5 sampling locations.

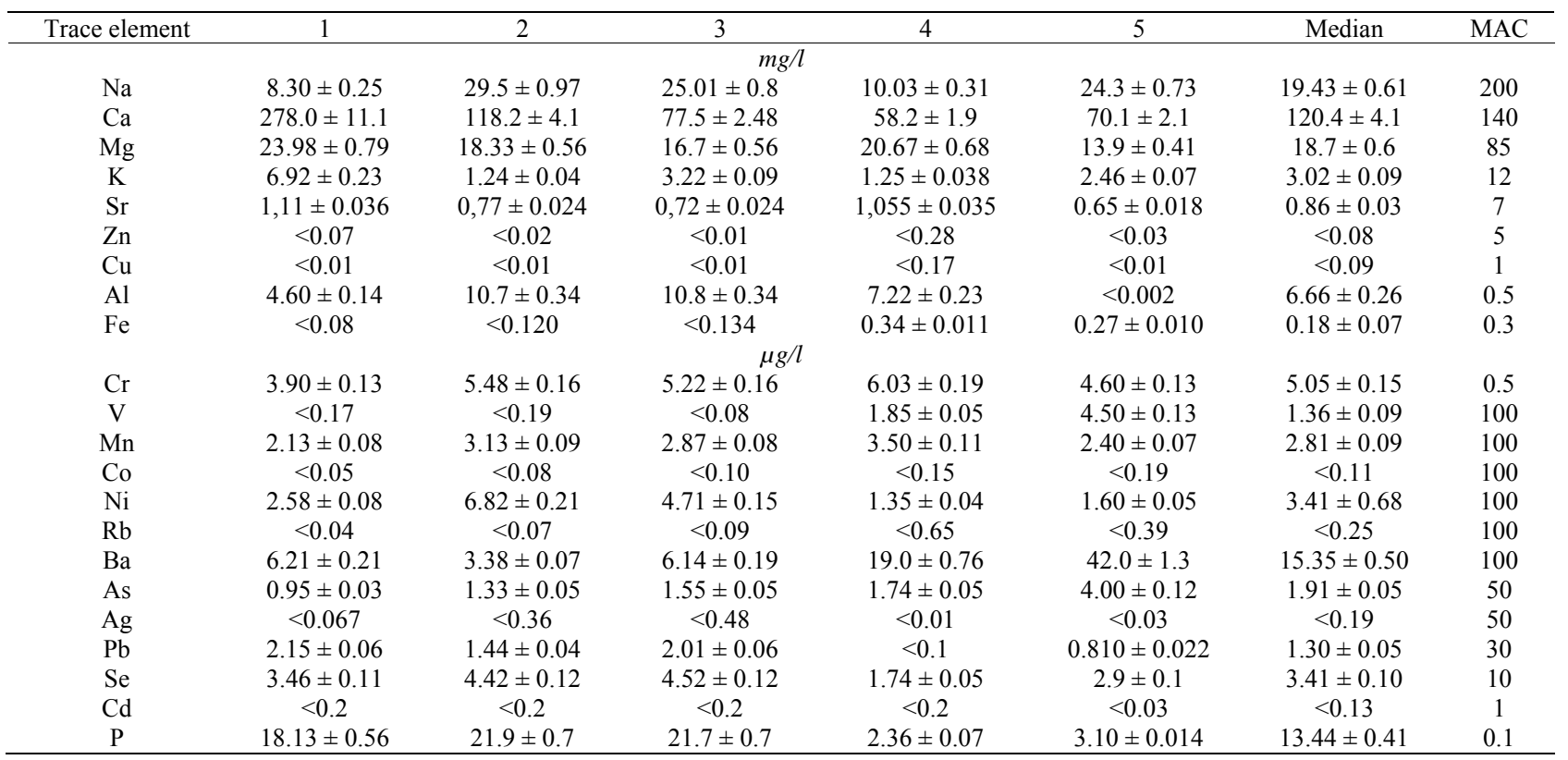



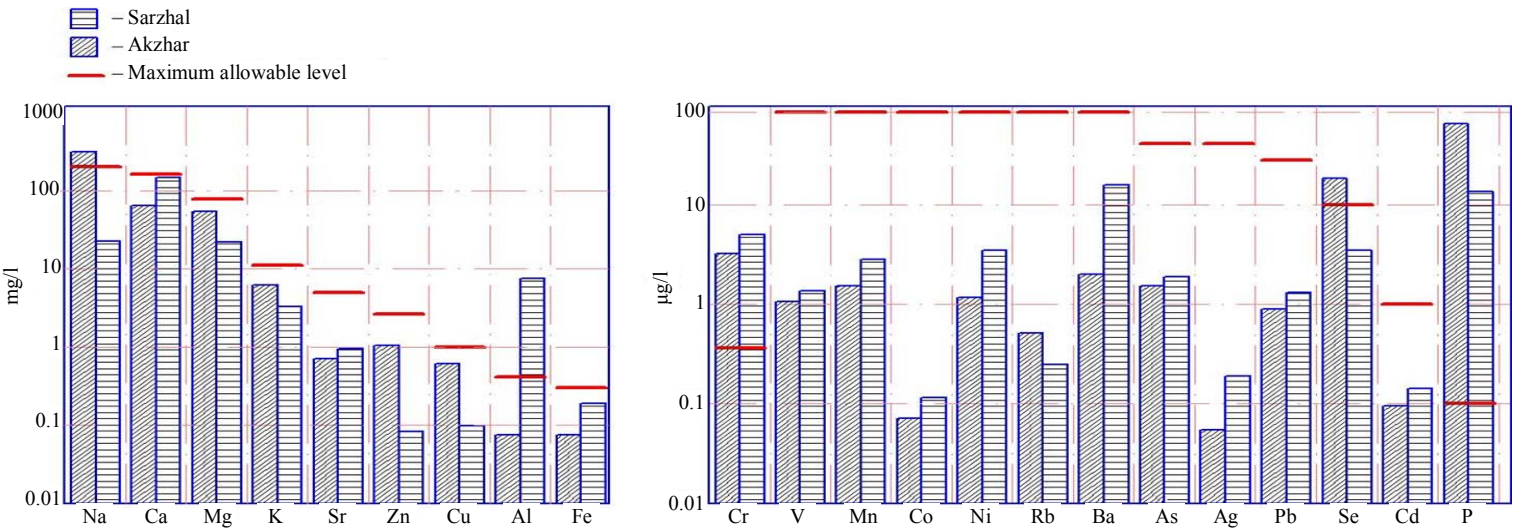

Figure 2. Level of trace elements in the rivers of Akzhar and Sarzhal villages.

Considering the median values and the distribution of trace element concentration, from the river waters obtained from Sarzhal and Akzhar, regional differences are apparent (Figure 2). While the concentrations of $\mathrm{K}, \mathrm{Sr}$, $\mathrm{Zn}, \mathrm{Cu} \mathrm{Cr}, \mathrm{V}, \mathrm{Mn}, \mathrm{Ni}, \mathrm{Rb}, \mathrm{As}, \mathrm{Ag}, \mathrm{Pb}$ and $\mathrm{Cd}$ were found to be similar in all samples, the content of the following trace elements increased from the Sarzhal to Akzhar rivers: $\mathrm{Na}$ from 19.43 to $252.0 \mathrm{mg} / \mathrm{l}, \mathrm{Mg}$ from 18.7 to 44.3 $\mathrm{mg} / \mathrm{l}$; Se from 3.41 to $18.16 \mu \mathrm{g} / \mathrm{l}$ and $\mathrm{P}$ from 13.44 to $64.56 \mu \mathrm{g} / \mathrm{l}$. However, the levels decreased for the following: from 120.4 to $54.8 \mathrm{mg} / \mathrm{l}$ for $\mathrm{Ca}$, from 6.66 to 0.07 $\mathrm{mg} / \mathrm{l}$ for $\mathrm{Al}$, from 0.18 to $0.07 \mathrm{mg} / \mathrm{l}$ for $\mathrm{Fe}$, from 0.11 to $0.07 \mu \mathrm{g} / \mathrm{l}$ for Co and from 15.35 to $2.0 \mu \mathrm{g} / \mathrm{l}$ for Ba.

\section{Conclusion}

From the data presented above, obvious differences in trace elements exist in the rivers of Sarzhal and Akzhar villages. In depth studies, including the quantification of trace, element distributions (heavy metals and radionuclides) in the water resources, are required to identify the sources and characterize contaminant migration such that actions can be taken to preserve/improve the quality of water used for drinking and farming.

\section{Acknowledgements}

The authors thank Professor Masaharu Hoshi (Hiroshima University, Japan) for his advices and constructive comments during the preparation of this paper.

\section{REFERENCES}

[1] S. Y. Ng, A. Zou, L. P. Sim, Y. Ding, K. L. Yuen, R. Y. C. Shin and T. K. Lee, "High Accuracy Measurements of Trace Elements in Drinking Water by Exact Matching Isotope Dilution Mass Spectrometry (IDMS)," International Journal of Mass Spectrometry, Vol. 321-322, 2012, pp. 19-24.

[2] E. Zubcov, N. Zubcov, A. Ene, N. Bagrin and L. Biletchi, "The Dynamics of Trace Elements in Dniester River,"
Journal of Science and Arts, Vol. 2, No. 13, 2010, pp. 281-286

[3] A. Jinwal, S. Dixit and S. Malik, "Some Trace Elements Investigation in Ground Water of Bhopal and Sehore District in Madhya Pradesh: India," Journal of Applied Sciences and Environmental Management, Vol. 13, No. 4, 2009, pp. 47-50.

[4] E. Merian, "Metals and Their Compounds in the Environment. Occurrence, Analysis and Biological Relevance," UCH, Weinheim, New York, Basel, Cambridge, 1991.

[5] P. O’Neil, "Environmental Chemistry," Chapman and Hall, London, 1993.

[6] T. M. Carlsen, L. E. Peterson, B. A. Ulsh, C. A. Werner, K. L. Purvis and A. C. Sharber, "Radionuclide Contamination at Kazakhstan Semipalatinsk Test Site: Implications on Human and Ecological Health," U.S. Department of Energy, 2001.

[7] T. Evseeva, E. Belykh, S. Geras'kin and T. Majstrenko, "Estimation of Radioactive Contamination of Soils from the 'Balapan' and the 'Experimental Field' Technical Areas of the Semipalatinsk Nuclear Test Site," Journal of Environmental Radioactivity, Vol. 109, 2012, pp. 52-59.

[8] O. N. Lyakhova, S. N. Lukashenko, N. V. Larionova and Y. S. Tur, "Contamination Mechanisms of Air Basin with Tritium in Venues of Underground Nuclear Explosions at the Former Semipalatinsk Test Site," Journal of Environmental Radioactivity, Vol. 113, 2012, pp. 98-107.

[9] A. M. Matushchenko, G. A. Tsyrkov, A. K. Chernyshov, Y. V. Dubashov, G. A. Krasilov, V. A. Logachev, S. G. Smagulov, Y. S. Tsaturov and S. A. Zelentsov, "Chronological List of Nuclear Tests at the Semipalatinsk Test Site and Their Radiation Effects," In: C. S. Shapiro, V. I. Kiselev and E. V. Zaitsev, Eds., Nuclear Test: Long-Term Consequences in the Semipalatinsk/Altai Region, NATO ASI Series, Environment, Vol. 36, 1998, Springer Publishers, New York, pp. 89-97.

[10] N. D. Priest, O. Artemyev, M. Burkitbayev, S. N. Lukashenko, P. I. Mitchell and L. Leon Vintro, "The Radiological Situation in the Sarzhal Region of the Semipalatinsk Nuclear Test Site-The NATO SEMIRAD Project," Proceeding of International Conference on Radioactivity in the Environment, Monaco, 1-5 September, 2002. 